\title{
ELAN VITAL ORANG BANJAR DI PERANTAUAN (Studi Kasus Migrasi dan Adaptasi Orang Banjar di Kabupaten Indragiri Hilir Provinsi Riau)
}

\author{
Edi Susrianto Indra Putra \\ FKIP, Universitas Islam Indragiri Tembilahan, Indragiri Hilir, Riau, \\ susriantoedi@yahoo.com
}

\begin{abstract}
This research is aim at studying the power struggle of Banjarese People in Indragiri Hilir Regency in which the focus of study is about the Banjarese People's migration and adaptation and it's implication to the social studies subject. The object of this research is to explore the causes of Banjarese People's migration such as; the motivating factors from the place of origin and the attractions from the place of destination. In addition, this research also describes the adaptation strategy, culture, and the role of Banjarese people's social capital which forms their power struggle in Shoreline. Further, the procedure of this research is qualitative research in the form of case study. The results of this research are; (1) the migration of Banjarese People is done because of the economy crisis and policy pressure at that time; (2) Indragiri Hilir is choosen as the migration place because it has the same geographic land with their place, thus it is easy for them to work there; (3) the adaptation and the social interaction of Banjarese People hold important role in managing and cooperating with other ethnics in Indragiri Hilir; (4) the social capital, especially the social networking holds important role in maintaining the banjarese identity ethnic in Shoreline.
\end{abstract}

Key words: Migration, Adaptation, Social Capital, Banjarese People's.

\section{PENDAHULUAN}

Migrasi sebagai suatu proses perpindahan penduduk, mengalami peningkatan yang cukup berarti pada dasawarsa belakangan ini. Peningkatan arus migrasi ini terjadi karena adanya perbedaan kondisi alam, sosial, ekonomi dan politik antarnegara yang satu dengan lainnya atau antardaerah yang satu dengan daerah yang lain. Terbatasnya sumber daya alam dan lapangan pekerjaan untuk memenuhi kebutuhan sosial ekonomi menjadi faktor dominan bagi penduduk untuk meninggalkan daerah asal mereka (Mantra, 1983; Naim, 1984; Pelly, 1994).

Orang Banjar yang ada di Kabupaten Indragiri Hilir adalah salah satu contoh etnis pendatang yang memiliki modal sosial yang baik. Keberhasilan mereka dalam beradaptasi dan berinteraksi dengan berbagai etnis yang ada di daerah ini, menjadikan orang Banjar sukses dan berhasil di daerah perantauan. Keberhasilan orang Banjar di Indragiri Hilir, tidak hanya ditopang dengan etos kerja baik, tetapi juga karena keberhasilan mereka dalam membangun jaringan 
sosial dan menjaga hubungan baik antar sesama etnis maupun dengan berbagai etnis yang ada di daerah ini (Mahdini, 2003:19; Hamidy, 1983:45). Peristiwa migrasi yang terjadi pada orang Banjar tidak terlepas dari kondisi politik, sosial dan ekonomi yang terjadi di daerah asal mereka Kalimantan Selatan. Ketika daerah mereka dilanda peperangan dan kesulitan ekonomi, mereka mencari daerah penghidupan baru dengan cara melakukan migrasi. Menurut catatan sejarah, orang Banjar sudah mulai masuk dan bermukim di daerah Indragiri sejak abad ke-19, yaitu pada masa pemerintahan Sultan Isa Mudayat Syah (Lutfi, 1976:321; Mahdini, 2003:9; Naim, 1984:42; Yusuf, 1994:20).

Penelitian yang pernah dilakukan sejumlah ahli (Coleman, 1988; Putnam, 1993; Fukuyama, 1995) memperlihatkan bagaimana peranan modal sosial yang dimiliki sebuah kelompok masyarakat (bonding social capital) yang dapat dimanfaatkan dalam hubungan antarkelompok masyarakat (bridging social capital). Studi ini memperlihatkan bagaimana modal sosial berperan dalam menjalin kerjasama antara masyarakat dan lembaga-lembaga pemerintahan. Keberhasilan ini dimungkinkan karena prinsip dasar modal sosial yang menekankan pentingnya menjaga hubungan baik dan kepercayaan antara sesama warga masyarakat dan berbagai lembaga-lembaga pemerintahan.

Kondisi daerah asal sangat mempengaruhi cara migran untuk melakukan migrasi ke daerah tujuan. Sarana dan prasarana transportasi sangat menentukan dalam melakukan migrasi. Sarana transportasi sangat menentukan gerak para migran untuk menuju daerah tujuan. Berbagai hasil penelitian menunjukkan bahwa proses migrasi penduduk tidak seluruhnya terjadi secara langsung (direct mobility), melainkan ada juga yang bertahap (indirect mobility), artinya para migran sampai di daerah tujuan terlebih dahulu menuju daerah transit (daerah yang tidak menjadi daerah tujuan utama migrasi).

Elan vital dalam penelitian ini lebih ditekankan pada bagaimana daya juang orang Banjar di perantauan dalam mengatasi berbagai tekanan, kesulitan, dan rintangan yang mereka alami. Keberhasilan mereka dalam menghadapi berbagai tantangan ini tidak terlepas dari modal sosial (social capital) dan jaringan sosial (social network) yang mereka miliki. Modal sosial yang dimaksud dalam penelitian ini adalah bentuk kerjasama yang diciptakan oleh orang Banjar dalam bentuk jaringan sosial yang dilandasi rasa saling percaya (reciprocal trust) antar etnis yang ada. Modal sosial dianggap sebagai landasan sosial kultural yang memiliki posisi penting untuk keberhasilan etnis dalam membangun jaringan sosial, baik antar sesama etnis maupun dengan berbagai etnis.

Penelitian ini mendeskripsikan tentang elan vital orang Banjar di Kabupaten Indragiri Hilir. Permasalahan yang akan diteliti difokuskan pada beberapa aspek, antara lain; (1) faktor-faktor migrasi orang Banjar ke Kabupaten Indragiri Hilir; (2) pola adaptasi orang Banjar di Kabupaten Indragiri Hilir; (3) peranan modal modal sosial terhadap pembentukan jaringan sosial orang Banjar; dan (4) bentuk kehidupan sosial orang Banjar di Kabupaten Indragiri Hilir. 


\section{METODE PENELITIAN}

Penelitian ini menggunakan pendekatan kualitatif. Alasan pemilihan metode kualitatif dikarenakan subjek penelitiannya adalah gejala-gejala sosial (social life) yang dinamis (Neuman, 1997:3237; Creswell, 1994:145). Dalam hal ini subject matter penelitian adalah dinamika sosial orang Banjar yang ada di Kabupaten Indragiri Hilir yang ditunjukkan dalam tindakan, aksi-aksi maupun berbagai dinamika sosial lainnya.

Pendekatan yang dilakukan dalam penelitian ini menggunakan jenis studi kasus (Creswell, 1994:154). Melalui pendekatan studi kasus, diharapkan dapat mengungkapkan tentang fenomena migrasi dan adaptasi orang Banjar di Kabupaten Indragiri Hilir. Studi kasus mempunyai ciri-ciri sebagai berikut; (1) identitas kasus direspon dalam suatu potret dan kondisi tertentu; (2) kasus yang dipilih pada dasarnya merupakan suatu sistem yang berdasarkan atau waktu dan tempat tertentu; (3) pemahaman kasus dapat diperluas dengan menggunakan berbagai sumber informasi, melalui pengumpulan data untuk memperoleh detail gambaran peristiwa; (4) penggambaran diarahkan pada konteks, terutama setting kasus, waktu, situasi kasus yang mengarah pada detail peristiwa. Langka-langkah penelitian ini dilakukan melalui proses selektif dan berulang-ulang, dengan maksud agar supaya kasus yang diteliti dapat difokuskan pada bukti-bukti untuk menjawab pertanyaan-pertanyaan penelitian yang muncul (Yin, 1981:23).

Penelitian ini mengambil lokasi di Kabupaten Indragiri Hilir Propinsi Riau dengan subjek penelitian adalah orang Banjar yang ada di daerah ini. Penentuan subjek penelitian ini dimaksudkan agar peneliti dapat sebanyak mungkin memperoleh informasi tentang berbagai permasalahan yang akan diteliti. Guna mengetahui tentang elan vital orang Banjar di Kabupaten Indragiri Hilir, peneliti menentukan subjek penelitian sesuai dengan kebutuhan (purposive). Peneliti di lapangan menjalin kerjasama dengan orang-orang Banjar dan juga dari berbagai kalangan etnis lain sebagai narasumber dalam penelitian ini. Mereka beraktifitas di berbagai bidang kehidupan masyarakat, seperti: akademisi, pengusaha, pendidik, ulama, budayawan, pengurus asosiasi, tokoh masyarakat, dan lain-lain. Semua itu dilakukan untuk menggali berbagai informasi yang berkaitan dengan masalah penelitian.

\section{HASIL DAN PEMBAHASAN}

\section{Faktor-faktor Migrasi orang Banjar ke Indragiri Hilir}

Perang Banjar sangat berpengaruh terhadap perkembangan politik, sosial budaya dan ekonomi masyarakat Banjar (Naim, 1984:42; Purwanto, 2000:57; Mahdini, 2003:9). Kondisi daerah yang kurang menguntungkan, ditambah dengan tekanan politik dari pemerintah kolonial Belanda, menimbulkan 
penderitaan yang berkepanjangan di kalangan orang Banjar ketika itu. Selama Perang Banjar berlangsung, perekonomian masyarakat menjadi sangat terganggu sehingga penduduk menjadi kehilangan gairah untuk bertani. Eksport katun dari Amuntai yang semula menguntungkan masyarakat, lambat laun merosot dan tidak menjanjikan lagi. Sehingga pada tahun 1858 ekspor ini terhenti sama sekali. Kondisi ini makin diperparah dengan adanya kewajiban membayar belasting dan kerja rodi yang diterapkan yang diterapkan oleh Pemerintah Kolonial Belanda. Kondisi seperti ini dirasakan sangat berat oleh orang Banjar ketika itu, merasa merasa tidak aman dan nyaman di kampung halamannya sendiri, sehingga memutuskan untuk pergi merantau ke tempat lain.

Berbagai penelitian menunjukkan bahwa proses migrasi penduduk tidak seluruhnya terjadi secara langsung (direct mobility), melainkan ada yang bertahap (indirect mobility), artinya para migran sampai di daerah tujuan terlebih dahulu menuju daerah transit (daerah yang tidak menjadi daerah tujuan utama migrasi). Mekanisme tahapan migrasi tersebut berlaku pula pada proses migrasi orang Banjar dari Kalimantan Selatan ke Indragiri Hilir. Berdasarkan hasil wawancara dan studi dokumentasi, diketahui bahwa migrasi orang Banjar ke Indragiri Hilir dilakukan melalui dua cara, yaitu secara langsung dan secara tidak langsung. Migrasi langsung adalah para migran yang berangkat dari Kalimantan Selatan menuju Indragiri Hilir. Sedangkan migran tidak langsung adalah migran yang berangkat dari Kalimantan Selatan menuju Indragiri Hilir, tetapi sebelum sampai ke daerah tujuan mereka pernah tinggal di daerah lain, seperti yang terjadi pada perantau Banjar di daerah Kuala Tungkal sebelum mereka menuju daerah Tembilahan. Mereka menetap terlebih dahulu di daerah Kuala Tungkal selama beberapa saat (bisa beberapa bulan bahkan sampai bertahun-tahun), lalu menyeberang menuju daerah Tembilahan. Proses migrasi seperti ini dikenal dengan istilah leaping frog (loncat katak).

Menurut Mantra (1999:183) pola loncat katak (leaping frog) yang dilakukan orang Banjar adalah sebagai salah satu strategi yang bertujuan untuk meningkatkan usaha dan mata pencaharian. Sehingga wilayah kesempatan antara dijadikan sasaran pertama untuk mencari pekerjaan. Setelah mereka merasa mapan dan sudah memiliki modal, mereka melompat ke daerah yang lain dimana terdapat kesempatan usaha yang lebih luas. Pola loncak katak ini juga didorong oleh faktor lancarnya aksesibilitas menuju daerah tujuan, sehingga dinamika pergerakan migran memberikan perubahan yang cukup besar, yang gilirannya memberikan peluang terhadap pertumbuhan ekonomi dan lapangan pekerjaan. Semakin membaiknya transportasi dan lancarnya jaringan komunikasi berpengaruh terhadap kondisi sosial, ekonomi dan kultural.

Pola loncat katak kebanyakan dilakukan oleh para migran Banjar setelah mereka berada di Indragiri Hilir dan Kuala Tungkal. Dengan menetap sekian lama di daerah ini, mereka baru menuju Selangor, Batu Pahat, Johor dan 
beberapa daerah yang ada di Semenanjung Malaysia. Menurut Arbain (2009:20) pola loncat katak (leaping frog) ini timbul akibat terjadi konflik orang Banjar dan orang Bugis ketika itu dalam memperebutkan daerah Kuala Tungkal Jambi. Akibat terdesak oleh orang Bugis, maka orang Banjar lalu pindah dan bermukim di Tembilahan. Daerah inilah yang selanjutkan di jadikan sebagai daerah basis loncatan bagi migran Banjar selanjutnya menuju ke berbagai daerah di Sumatera dan Semenanjung Malaysia.

Mobilitas yang dilakukan orang Banjar ini dipengaruhi oleh beberapa faktor, antara lain; (1) sebagaimana yang dijelaskan dalam beberapa teori migrasi, bahwa tekanan ekonomi daerah asal cendrung menyebabkan seseorang atau kelompok untuk mengambil keputusan melakukan migrasi; (2) di samping karena tekanan ekonomi, tekanan politik dan sosial kultural juga mendorong seseorang atau kelompok melakukan migrasi; (3) keberhasilan di daerah tujuan, memiliki kecendrungan mereka untuk tinggal menetap. Di daerah rantau mereka akan memanggil sanak kerabatnya untuk mendukung usaha yang telah mereka lakukan; dan (4) ketidakberhasilan mereka di perantauan, mendorong mereka untuk melakukan mobilitas ke daerah lain yang memiliki nilai kefaedahan yang lebih baik, ketimbang harus pulang ke daerah asal.

\section{Pola Adaptasi dan Interaksi orang Banjar di Indragiri Hilir}

Adaptasi merupakan sistem dan dinamika pergaulan dalam kehidupan setiap kelompok masyarakat majemuk. Karena itu, kemajemukan biasanya merupakan salah satu ciri yang menonjol pada masyarakat perkotaan. Adaptasi sosial yang terjadi di wilayah perkotaan akan selalu berbeda di antara berbagai kelompok masyarakat yang melakukannya. Perbedaan-perbedaan seperti ini biasanya muncul disebabkan karena latar belakang sosial budaya, kepentingan yang ingin dicapai, serta misi budaya yang akan dikembangkan (Pelly, 1994:1).

Interaksi sosial orang Banjar di Kabupaten Indragiri Hilir, umumnya terjadi secara alamiah sesuai dengan jenis pekerjaan yang mereka lakukan. Di kota Tembilahan, pola interaksi sosial mereka lakukan dalam bentuk hubungan transaksi dagang, misalnya antara penjual dan pembeli yang berkomunikasi tentang jenis barang, kualitas barang, dan harga barang yang dibeli. Sedangkan interaksi yang dilakukan orang Banjar yang bekerja sebagai Pegawai Negeri, baik sebagai guru, pegawai pemerintah, TNI/Polisi juga tidak jauh berbeda, meskipun pola hubungan dari kelompok ini terjadi karena adanya ikatan kedinasan yang mengharuskan mereka membuka ruang interaksi dalam sebuah tim kerja guna mencapai tujuan-tujuan organisasi dan institusi dimana mereka bekerja. Interaksi ini dijelaskan pula oleh faktor-faktor kepentingan kerja dan faktor tingkat pendidikan yang turut mempengaruhi pola interaksi diantara mereka.

Berdasarkan hasil observasi dan wawancara di lapangan, ada tiga kategori proses adaptasi orang Banjar di Kabupaten Indragiri Hilir, yaitu; proses 
adaptasi secara cepat, proses adaptasi sedang dan proses adaptasi lambat. Proses adaptasi secara cepat umumnya terjadi pada migran Banjar yang memiliki kemampuan yang baik, seperti kemampuan berbahasa, kemampuan dalam memahami nilai-nilai budaya, kesamaan jenis pekerjaan, dan tingkat pendidikan. Proses adaptasi sedang biasanya terjadi pada migran Banjar yang mengalami masa krisis yang relatif lebih lama dan mereka harus bekerja keras dalam menghadapi berbagai persoalan di daerah tujuan. Mereka yang mengalami masa seperti ini pada umumnya adalah mereka yang mempunyai kemampuan cukup, seperti bahasa, tingkat pendidikan, status sosial, dan lain sebagainya. Sedangkan proses adaptasi lambat terjadi pada para migran yang mengalami berbagai keterbatasan dan tidak memiliki kemampuan dalam melakukan berbagai interaksi sosial, dan mengalami berbagai keterbatasan, seperti faktor bahasa, tingkat pendidikan, status sosial dalam masyarakat, dan lain-lain sebagainya. Umumnya mereka ini mengalami masa krisis yang cukup lama dengan tingkat ketidaknyamanan, tidak mampu bertahan di daerah tujuan dan akhirnya harus pulang ke daerah asal atau mencari daerah tujuan yang baru.

Orang Banjar dalam kehidupan mereka sehari-hari selalu menjunjung tinggi ajaran dan prinsip hidup yang mereka anut. Pesan moral ini selalu mereka sampaikan secara turun temurun, tujuannya adalah untuk dijadikan pedoman dalam kehidupan sehari-hari. Ajaran-ajaran tersebut dijelaskan dalam ungkapan-ungkapan yang sering disampaikan, seperti: "makan acan makan bawang, jangan jadi acan di kampung urang, jangan manjadi rumput yang maalahan banua". Ungkapan-ungkapan seperti ini menjadi salah satu modal bagi orang Banjar dalam bergaul dan menghargai orang lain. Ungkapan-ungkapan tersebut memiliki makna tentang bagaimana seorang perantau harus bersikap di negeri orang dan harus pandai-pandai menyesuaikan diri di daerah rantau. Hal ini sejalan dengan ungkapan "dimana bumi dipijak, disitu langit dijunjung".

Tradisi keagamaan yang dianut oleh orang Banjar, menyebabkan mereka mudah diterima dengan baik oleh di berbagai kalangan etnis yang ada. Dalam pandangan etnis lain, etnis Banjar adalah orang yang taat dalam menjalankan ibadah dan ritual agama Islam. Hal ini tentu tidak terlepas dari peranan ulama seperti Syekh Abdurrahman Siddiq, yang telah berjasa dalam memberikan pemahaman terhadap agama Islam. Bahkan beberapa kitab karangan beliau menjadi bahan rujukan tidak hanya oleh kalangan orang Banjar, tetapi umat Islam yang ada di Kabupaten Indragiri Hilir.

\section{Peranan Modal Sosial dalam Pembentukan Jaringan Sosial}

Jaringan sosial sebagai salah satu bagian dari modal sosial merupakan bentuk hubungan sosial yang terjadi di tengah-tengah masyarakat. Jaringan sosial merupakan seperangkat hubungan-hubungan khusus yang terbentuk di antara sekelompok orang, dimana karakteristik hubungan-hubungan tersebut dapat digunakan untuk menginterpretasikan motif-motif perilaku sosial dari 
orang-orang yang terlibat di dalamnya. Pada umumnya setiap kelompok migran selalu membentuk suatu jaringan sosial yang terbentuk dalam suatu paguyuban atau asosiasi sukarela.

Dari hasil wawancara di lapangan, diperoleh informasi bahwa ada tiga bentuk jaringan sosial yang dikembangkan oleh orang Banjar di Kabupaten Indragiri Hilir, yaitu; (1)jaringan sosial yang didasarkan pada sistem kekerabatan dan kekeluargaan, khususnya dengan migran yang sedaerah asal. Jaringan sosial semacam ini sengaja dibentuk dan dikembangkan oleh para migran sebagai salah satu strategi dalam mengatasi persoalan yang mereka hadapi dan mempertahankan kehidupan mereka di daerah yang baru; (2) jaringan sosial yang dibentuk dan dikembangkan dengan kelompok-kelompok sosial dalam pola hubungan sosial-vertikal, yaitu dengan orang-orang yang memiliki kegiatan usaha; (3) jaringan sosial dibentuk pada kelompok-kelompok sosial baru guna saling memenuhi kebutuhan di antara migran. Kelompok sosial ini bisa bermacam-macam bentuk, misalnya; kelompok ketetanggaan, kelompok orang yang tinggal bersama, kelompok orang dengan nilai-nilai baru yang muncul di kota, kelompok ini muncul karena terjadi kesamaan agama, profesi, dan sebagainya.

Keberadaan jaringan sosial memainkan peranan penting dalam mempertahankan identitas etnis di perantauan. Jaringan sosial ini berkembang seiring dengan proses adaptasi yang dilakukan para migran dengan daerah tujuan. Memahami prinsip tersebut, dimana nampak dalam kehidupan migran Banjar berinteraksi dengan etnis lainnya di Kabupaten Indragiri Hilir, yang mana mereka tetap menjaga dan menjalin keharmonisan hubungan kerjasama yang baik di antara sesama warga masyarakat sekitar. Biasanya mereka melakukan kerjasama dalam kegiatan-kegiatan kemasyarakatan, seperti tolong menolong jika ada yang mengalami musibah atau kesusahan, saling mengundang apa bila ada yang melakukan syukuran atau perkawinan, bergotong royong membersihkan dan membangun lingkungan sekitarnya, menjaga ketertiban dan keamanan lingkungan, saling mengunjungi dan bersilaturrahmi pada saat hari-hari raya besar keagamaan.

Dalam menjalankan bisnisnya, orang Banjar yang ada di Indragiri Hilir, terbilang sukses dan berhasil. Hal ini didasari pada kerja keras, ketekunan dan naluri bisnis yang telah melekat pada etnis tersebut secara turun temurun. Berdasarkan hasil observasi dan wawancara, diperoleh informasi bahwa ada tiga karakteristik bisnis yang dijalankan oleh orang Banjar, yaitu; (1) bersifat paternalistik, yaitu prinsip penghormatan kepada pimpinan atau orang yang lebih tua atau dituakan dalam keluarga, sehingga mereka tetap patuh, taat, loyal dan penuh pengabdian kepada mereka. Hal ini dengan ciri utama adalah kekuasaan selalu terpusat, lebih bersifat kekeluargaan (nepotisme), atau hanya jaringan keluarga terdekat (bubuhan), kekuasaan di tangan pemiliknya dengan sistem warisan tradisional; (2) personalistik, yaitu mengutamakan kepercayaan informal ketimbang kepercayaan formal. Kepercayaan ini merupakan modal 
utama dalam kegiatan bisnis. Dalam hal ini kegiatan menjalin hubungan mutlak dilakukan, yaitu membangun jaringan bisnis melalui hubungan pribadi, sehingga mempunyai koneksi yang tetap. Di samping itu loyalitas bukan karena kemampuan, tetapi lebih bersifat pribadi, kekeluargaan dan kepercayaan; (3) warisan budaya, yang mengharuskan mereka untuk menggantungkan pada sumber pendapatan kelurga dalam bentuk menumpuk harta kekayaan. Hal ini dibuktikan dengan berbagai investasi, seperti pembelian tanah, rumah, barangbarang berharga, yang bertujuan sebagai bekal hidup untuk keturunan mereka.

Kesulitan dan kekerasan hidup yang dialami orang Banjar pada saat tinggal di daerah asal, menjadikan mereka tidak mudah menyerah dan rentan diterpa badai kesulitan. Ungkapan "hulat dalam batu gin ada rajakinya, biar jadi habu jadi harang" (ulat di dalam batu juga memiliki rezeki, tidak peduli meski harus jadi abu atau jadi arang sekalipun) betul-betul menjadi pegangan hidup mereka di perantauan. Berbekal keahlian yang mereka miliki dalam bercocok tanam dan penguasaan dibidang pertanian, mereka mulai membuka persawahan dan ladang. Jika pada awal kedatangan mereka menyuplai bahan-bahan kebutuhan pangan dari penduduk setempat, lambat laun ketergantungan ini dapat mereka atasi. Artinya mereka dapat memenuhi kebutuhan hidup sendiri, bahkan dalam perkembangannya mereka kemudian menggantikan peran masyarakat setempat untuk menyuplai kebutuhan bahan-bahan pokok, seperti beras, kelapa, sayur-sayuran, dan lain-lain. Ini menunjukkan bahwa, orang Banjar yang semula hanya melibatkan diri dalam dunia pertanian dan perkebunan, lambat laun mulai terjun kedunia bisnis perdagangan. Berkat usaha dan kerja keras serta jaringan sosial yang mereka miliki, akhirnya mereka tumbuh dan berkembang menjadi pedagang yang sukses. Ini menunjukkan, bahwa orang Banjar tidak hanya menguasai teknik dan ilmu pertanian saja, tetapi mereka juga ahli dalam dunia bisnis perdagangan.

\section{Bentuk Kehidupan Sosial Budaya orang Banjar di Kabupaten Indragiri Hilir}

Orang Banjar memposisikan dirinya sebagai komunitas etnik yang umumnya tinggal disekitar pantai dan aliran sungai dan penganut agama Islam yang taat. Istilah Banjar sendiri bukan sekedar konsep etnis saja, akan tetapi juga sekaligus merupakan konsep politis, sosiologis, dan agamis. Artinya masyarakat Banjar adalah masyarakat Islam karena memang mayoritas mereka memeluk agama Islam yang taat dan bahkan cenderung fanatik. Dengan identitas inilah yang membedakan antara orang Banjar dengan berbagai etnis lain. Tetapi bukan berarti seluruh kepercayaan lama dibabat habis oleh masyarakat Banjar sesudah mereka memeluk agama Islam, melainkan masih terdapat sisa-sisanya yang diserap menjadi satu kesatuan mata rantai dalam ajaran Islam terutama hal-hal yang tidak bertentangan dengan nilai-nilai esensialnya. Sedangkan bahasa yang dipakai oleh orang Banjar adalah bahasa Banjar yang elemen bahasa Melayu yang sangat dominan. 
Kehidupan sosial orang Banjar di Kabupaten Indragiri Hilir dipengaruhi oleh beberapa faktor yang menyebabkan terjadi proses interaksi sosial yang harmonis terhadap etnis lainnya, yaitu; (1) orang Banjar adalah salah satu kelompok etnis yang memiliki sifat dan karakter yang mudah dan cepat menyesuaikan diri dengan lingkungan masyarakat setempat; (2) sistem kekerabatan dalam keluarga orang Banjar yang menganut paham bubuhan, merupakan salah satu ciri khas yang biasanya mendasari cara memandang orang lain sebagai sahabat yang sangat penting dalam kehidupan seharihari; (3) orang Banjar yang mayoritas beragama Islam, mengajarkan tentang pentingnya untuk saling mengasihi dan menyayangi sesama manusia tanpa membedakan dari mana asalnya; (4) orang Banjar sebagai perantau, biasanya selalu mengutamakan sifat rendah hati dan suka bekerja keras, sehingga masyarakat tempatan mudah menerimanya.

Agama dan kebudayaan memegang peranan penting dalam kehidupan masyarakat Banjar. Keduannya sama-sama menguntungkan, bukan menegangkan, apalagi merugikan. Sebab harmonisasi antara keduanya terletak pada fungsi masing-masing. Menurut Kuntowijoyo (1991) agama dalam perspektif ilmu-ilmu sosial adalah sebuah sistem nilai yang membuat sejumlah konsepsi mengenai konstruksi realitas, yang berperan besar dalam menjelaskan struktur tata normatif dan tata sosial serta memahamkan dan menafsirkan dunia sekitarnya. Sementara itu, seni dan tradisi merupakan ekspresi cipta, karya, dan karsa manusia yang berisi nilai-nilai dan pesan-pesan religius, wawawasan filosofis dan kearifan lokal (local wisdom). Sedangkan menurut Azra (2003) agama dan kebudayaan adalah dua hal yang sama-sama menguntungkan. Agama akan member spirit pada kebudayaan, sedangkan kebudayaan memberikan kekayaan terhadap agama.

\section{SIMPULAN}

Migrasi orang Banjar ke Kabupaten Indragiri Hilir tidak terlepas dari perkembangan politik, sosial dan ekonomi yang terjadi di daerah asal mereka pada waktu itu. Tekanan politik dari pemerintah kolonial Belanda dalam bentuk kewajiban membayar pajak (belasting) dan sistem kerja rodi yang diterapkan oleh pemerintah kolonial Belanda, membuat masyarakat menjadi semakin menderita. Terbatasnya lapangan pekerjaan, merosotnya hasil pertanian, menjadikan penderitaan yang berkepanjangan di kalangan masyarkat Banjar. Kondisi ini dirasakan sangat berat, orang Banjar merasa tidak nyaman lagi di kampung halaman mereka sendiri, sehingga memutuskan melakukan migrasi ke daerah yang baru.

Adaptasi di daerah tujuan terjadi lewat struktur relasi kelompok sesama etnis, interaksi antara sesama etnis pendatang, maupun dalam bentuk pemanfaatan sarana asosiasi sukarela atau paguyuban. Perwujudan dalam melakukan interaksi sosial bagi para migran di daerah tujuan, biasanya 
dilakukan dalam bentuk bertamu, berteman, kegiatan sosial, acara keagamaan, dan lain-lain. Dalam hal ini, modal sosial memegang peranan penting dalam mempertahankan identitas migran di perantauan. Jaringan sosial ini berkembang seiring dengan proses adaptasi yang dilakukan para migran dengan daerah tujuan.

\section{DAFTAR PUSTAKA}

Azra, A. (2003). Surau, Pendidikan Islam Tradisional dalam Transisi dan Modernisasi. Jakarta: Logos Wacana Ilmu.

Bourdiue, P. (1986). "The Froms of Capital", in John G. Richardson (edt), Handbook of Theory and Research in the Sociology of Education. New York: Greenwald Press.

Coleman, J. S. (1988). "Social Capital in the Creation of Human Capital". The American Journal of Sociology, Vol. 94. pp. S95-S120.

Creswell, J. W. (1994). Research Design Qualitative \& Quantitative Approachhes. SAGE Publications International Educational and Professional Publisher Thousand Oaks London New Delhi.

De Jong, G. F and Fawcett, J. T . (1981). "Motivation for Migration: An assessment and value expactancy research model". In F. de Jong and Robert W. Gardner (eds). Migration Decision Making Multidisciplinary Approach to Micro level studies Studies in developmen Countries. Pergam Press USA. p. 213-228.

Field, J. (2010). Modal Sosial. Yogyakarta: Kreasi Wacana.

Putnam, R. D. (1993). Making Democracy Work: Civic Tradition in Modern Italy. Princenton: Princenton University Press.

Fukuyama, F. (1995). Trust: The Social Virtues and The Creation of Prosperity. New York: The Free Press.

Hamidy, U. U. (1983). Beberapa Aspek Sosial Budaya daerah Riau. Pekanbaru: UIR Press.

Jalil, A. (1990). Migrasi Penduduk ke Pulau Batam. Tesis. Yogyakarta: Fakultas Pasca Sarjana Universitas Gajah Mada. Tidak diterbitkan..

Kuntowijoyo. (1991). Dinamika Sejarah Umat Islam di Indonesia. Yogyakarta: Salahuddin Press.

Lee, E. S. (2000). Suatu Teori Migrasi. (terjemahan). Yogyakarta: Lembaga Kependudukan Kependudukan Universitas Gadjah Mada.

Linton, R. (1976). Antropologi, Suatu Penyelidikan tentang Manusia. Bandung: Jemmars.

Lutfi, M. et.al. (1976). Sejarah Riau. Pekanbaru. Pemerintah Daerah Propinsi Riau.

Mahdini. (2003). Sastra Lisan Orang Banjar. Pekanbaru: Daulat Riau.

Mantra, I. B. (1983). Migrasi Penduduk di Indonesia. Yokyakarta: Pusat Penelitian Studi Kependudukan, Universitas Gajah Mada. 
Mantra, I. B. (1999). Mobilitas Sirkuler dari Desa ke Kota di Indonesia. Yogyakarta: Pusat Penelitian Studi Kependudukan Universitas Gajah Mada.

Naim, M. (1984). Merantau, Pola Migrasi Suku Minangkabau. Yokyakarta: Gajah Mada University Press.

Neuman, W. L. (1997). Social Reserch Methods Qualitative and Quantitative Approach. Boston: Allyn Bacon.

Pelly, U. (1994). Urbanisasi dan Adaptasi: Peranan Misi Budaya Minangkabau dan Mandailing. Jakarta: LP3ES.

Purwanto, B. (2000). “Merajut Jaring di Tengah Perubahan Komunitas Ekonomi Muslim di Indonesia pada Masa Kolonial". Lembaran Sejarah, Volume 2 No. 2 . hal. 57.

Putnam, R. D. (1993). Making Democracy Work: Civic Tradition in Modern Italy. Princenton: Princenton University Press.

Soemarwoto, O. (1997). Ekologi Lingkungan Hidup dan Pembangunan. Jakarta: Penerbit Djambatan.

Soekanto, S. (2007). Sosiologi Suatu Pengantar. Jakarta: Rajawali Press.

Spradley, J. P. (1972). The Ethnographic Interview. California: Wadsworth Publishing Company, Belmont.

Todaro, M. P. (1976). Kajian Ekonomi Migrasi Internal di Negara Berkembang: Telaah Atas Beberapa Model. Yogyakarta: Pusat Penelitian dan Studi Kependudukan Universitas Gajah Mada.

Veeger, K. J. (1993). Realitas Sosial. Jakarta: Gramedia.

Yin, R. K. (1997). Studi Kasus, Desain dan Metode. Jakarta: PT. Raja Grafindo Persada.

Yusuf, A. (1994). Sejarah Kesultanan Indragiri. Pekanbaru; Pemerintah Daerah Propinsi Riau. 